University of Michigan Law School

University of Michigan Law School Scholarship Repository

\title{
What They Say at the End: Capital Victims' Families and the Press
}

Samuel R. Gross

University of Michigan Law School, srgross@umich.edu

Daniel J. Matheson

Available at: https://repository.law.umich.edu/articles/911

Follow this and additional works at: https://repository.law.umich.edu/articles

Part of the Criminal Law Commons, and the Law and Psychology Commons

\section{Recommended Citation}

Gross, Samuel R. "What They Say at the End: Capital Victims' Families and the Press (Symposium: Victims and the Death Penalty: Inside and Outside the Courtroom)." D. J. Matheson, co-author. Cornell L. Rev. 88, no. 2 (2003): 486-516.

This Article is brought to you for free and open access by the Faculty Scholarship at University of Michigan Law School Scholarship Repository. It has been accepted for inclusion in Articles by an authorized administrator of University of Michigan Law School Scholarship Repository. For more information, please contact mlaw.repository@umich.edu. 


\title{
WHAT THEY SAY AT THE END: CAPITAL VICTIMS' FAMILIES AND THE PRESS
}

\author{
Samuel R. Gross $\dagger$ \\ $\mathcal{E}$ Daniel J. Matheson††
}

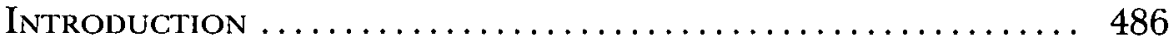

I. Executions ................................... 489

A. Closure .............................. 490

B. Justice and Vengeance...................... 494

C. Compassion ........................... 497

D. Clemency and Intrafamilial Conflict ............ 498

E. Intrafamilial Killings ....................... 500

F. Apology and Forgiveness ................... 501

II. Exonerations ................................ 505

A. Position on the Defendant's Innocence .......... 507

B. Identifying the Real Killer ................. $5 \mathrm{I} 0$

C. Trust in Local Law Enforcement............... 511

Conclusion .................................... 514

\section{INTRODUCTION}

Perhaps the most common complaint by American crime victims and their families is that they are ignored-by the police, by the prosecutors, by the courts and by the press. However true that may be for capital cases in general, there is at least one consistent exception: the great majority of newspaper accounts of executions include at least some description of the reactions of the victims' families and of any surviving victims. It seems to have become an item on the checklist, part of the "who, what, where, when, why, and how" of execution stories. When no family members are available, or they refuse to speak, that fact is usually noted as well.

Execution stories are hardly a reliable source of information about the effects on victims' families of murders and executions-and all that happens in between. We only have such reports in the comparatively few capital cases that end in execution, and not for all of

$\dagger$ Thomas G. and Mabel A. Long Professor of Law, University of Michigan Law School. The authors thank Michael Groebe, Kristy Lewis, Aimee Mangan, Yarmela Pavlovic, Katherine Taylor, Judith VanHoose and Laura Varela for their help in locating the news stories on which this Article is based. This research was supported by the Cook funds of the University of Michigan Law School.

t† B.A., Case Western Reserve University, 1998; candidate for J.D., University of Michigan Law School, 2004. 
those. The family members who make statements to the press are undoubtedly not a representative sample of victims' families at large, even among cases that do end in execution. At a guess, they are probably more likely to favor execution than those who do not show up or do not speak, and less likely to have come to terms with the murder. They may also be more articulate and vocal, higher status, and more likely to live in the vicinity of the execution. In addition, the reported stories are neither a complete nor an unmediated reflection of the views of those family members who do speak to the press. Strictly speaking, we can talk only about what they are reported to have said, which may tell us as much about reporters and their editors as it does about the families of murder victims.

Nonetheless, in a world that provides very little systematic information about the families of the victims in capital cases, looking at press stories on what some of them say is a start. We have done that here for some of the more recent executions in the United States. Specifically, we gathered news stories from the Lexis and Westlaw databases on 100 of the 101 executions that took place in the eighteen-month period from January 2001 through June 2002. ${ }^{1}$ For 68 of those executions, the stories refer to statements by members of the victims' families. In addition, we compiled a much less complete set of news stories on 70 of the 183 executions that took place in 1999 and 2000, including only those executions in that two-year period for which we found post-execution reports that mention statements by family members of the victims.

Neither set is a representative sample of news stories on executions. We made no attempt to collect all of the dozens or hundreds of news stories on several heavily covered executions (for example, Juan Garza's execution in June 2001), and undoubtedly missed other stories that are available on Lexis and Westlaw. More important, Lexis and Westlaw include only a small minority of the general circulation newspapers in the United States ${ }^{2}$-only some 225 out of about

1 We omitted the case of Timothy McVeigh, who was executed on June 11, 2001, for blowing up the Murrah Federal Building in Oklahoma City, killing 168 people and injuring scores more. McVeigh's case involved so many victims and was so heavily publicized that it bears little resemblance to other capital prosecutions. It certainly could not be usefully described for the purposes of this Article, because readily available stories include countless reactions from dozens if not hundreds of relatives of victims, who say many different things.

2 Moreover, the coverage of the Westlaw and Lexis databases is weighted toward business newspapers. Westlaw carries twenty-two Ohio news sources, for example, nine of which are focused on small business news. See WESTLAw, Ohnews File. One advantage of these databases is that they include twenty-three wire services, from which many smaller newspapers get information. However, these wire services are the least likely to carry longer stories focusing in more detail on the reactions of local figures to an execution or exoneration. 
$1,500 .^{3}$ Some of the most interesting stories that we found appeared in local papers from the areas where the murders took place; other stories that are equally interesting-or more so-no doubt appeared in papers that are too small to have made it onto the radar screen. ${ }^{4}$ Nonetheless, the news stories we have collected are interesting and suggestive. If nothing else, they illustrate, sometimes dramatically, the reactions of victims' families to executions and the newspapers' interpretations of those reactions. However, only the clearest patterns that appear in these stories can be used for even the most tentative generalizations about victims' families' reactions to executions in general.

In addition to the execution stories, we have also assembled a set of stories on how victims' families have reacted when the defendant who was sentenced to death for the murder of their relative is released because he has been proven innocent. There have been a surprisingly large number of recent death row exonerations in the United States (102 since $1973^{5}$ ) but they are still far less common than executions, which have averaged about 75 per year in the past several years. ${ }^{6}$ As a result, we have collected every story that we could locate on Lexis or Westlaw that includes a report on the reaction of one or more family members to the release of an exonerated death row inmate, a set that includes 34 exonerated defendants all told. Unfortunately, such stories are much more common for recent exonerations than for older ones. We have stories that refer to the reactions of the victims' families for 13 of the 16 death row inmates who have been released since $2000(76 \%)$, and for 21 of the 52 exonerations from 1988 through 1999 (42\%), but none for any of the 33 exonerations before $1988 .{ }^{7}$ In part, this pattern may be due to changes in coverage of the Lexis and Westlaw databases over time. ${ }^{8}$ In part, it also may reflect an increase

3 There were 1,480 daily English-language newspapers published in the United States in 2000. U.S. Census Bureau, Statistical Abstract of the United States: 2001, at 706 (121st ed.).

4 Of these 1,480 dailies, 1,027 were published in cities with a population of less than 50,000. See id. at 707 .

5 See Death Penalty Info. Ctr., Innocence: Freed from Death Row, at http://www. deathpenaltyinfo.org/lnnocentlist.html (last visited Nov. 10, 2002).

6 See Death Penalty lnfo. Ctr., Number of Executions by Year Since 1976, at http:// www.deathpenaltyinfo.org/dpicexec.html (last visited Nov. 10, 2002).

$7 \quad$ See Death Penalty Info. Ctr., supra note 5.

8 For instance, Westlaw provides archives of Washington Post articles dating back to January 1984, Atlanta Joumal and Constitution articles dating back to January 1986, and full Tulsa World coverage dating back to January 1989. Westlaw also provides New York Times abstracts dating back to January 1990, as well as same-day articles. Lexis provides Nerv York Times abstracts dating back to January 1969, and complete archives dating back to January 1980. Lexis also provides Washington Post archives dating back to January 1977, Atlanta Joumal and Constitution articles dating back to January 1991, and Tulsa World archives dating back to December 22, 1995. 
in the attention the national media has paid to exonerations of death row prisoners.

\section{I \\ EXECUTIONS}

If there is any dominant theme in the statements that victims' family members make to the press after executions it is pain. They have suffered, and continue to suffer, and their suffering is unmistakable even in this flat and stylized medium. Beyond that, the only safe generalization is that the reaction of the victim's family is a recognized part of the story of an execution, a fixture in news reports. Statements by members of the victims' families are discussed in two-thirds of the stories on executions in 2001 and 2002 for which we have found news reports ( 68 out of 100 ). Fifteen additional stories in that set mention that members of the victims' families were present at the execution but made no statement, and 7 mention that no family members were present. In only 10 of these 100 executions did the news stories we found fail to mention the victims' families. In at least 29 of the executions from both time periods we covered (over one-fifth of the total), the families foresaw press interest in their reactions and issued formal public statements.

All told, the news stories on which this Article is based cover I38 executions for which some statement by the victims' family is reported (68 in 2001-2002; 70 in 1999-2000). In content, the statements made by family members of victims vary widely. They express a wide range of reactions, desires and hopes-sometimes contradictory ones. Some relatives are vindictive; others, fewer, are compassionate; many want recognition of their loss; and most clearly want to get through this ordeal with the feeling that they have done the right thing. The most common issue, which is mentioned in over a third of these cases, is "closure"- the survivors say that they hope they will be able to put the murder behind them or fear that they will never be able to do so. In about one-fourth of the cases the relatives are reported to have said that justice was done. In about an equal number of cases (sometimes the same ones) they focus on revenge-expressing satisfaction that it was achieved, disappointment that the killer got off too easily, or hope that the killer truly suffered. Over one-third of the stories also mention that the defendant apologized for his crimes, or that he asked for forgiveness, but the victims' families themselves are only reported to have mentioned apology and forgiveness (or their absence) in about two-thirds of those cases. In a comparatively small number of casesperhaps one-sixth of the total-the victims' relatives are reported to have asked for clemency for the defendant or to have expressed compassion for the defendant or for the defendant's family. 


\section{A. Closure}

In 49 of these 138 executions family members expressed a clear desire for their ordeal to be over. These statements took many forms. Some are simple and direct. When Caruthers Alexander was executed in Texas in January 200I for murdering Lori Bruch nearly twenty years earlier, the victim's family issued a press statement, stating, in part: "Today marks the end of a very long and tragic chapter in our lives and we are relieved [that] it is over." ${ }^{9}$ The survivors realize, of course, that the execution will not stop the suffering caused by the murder itself, but will only bring an end to the legal aftermath of that crime. After Gregg Braun was executed in July 2000, for example, the widower of one of his victims said, "I'm glad to get this over with ... but I'm still very angry that he's taken my wife and my children's mother away."10

In some cases, victims' relatives explain the relief they feel after the execution in apparently concrete terms: Now the defendant is no longer a threat to them or to anybody eIse. ${ }^{11}$ When Billy Hughes was executed in Texas in January 2000, for example, his victim's mother said, "Mark can now rest in peace and our nightmares will end knowing Bill Hughes will not take another life." 12 These fears are almost inevitably unrealistic, sometimes obviously so. Hughes had spent twenty-four years on death row, apparently without serious incident and could no doubt have been safely confined indefinitely. The continuing terror generated by these murders, however, is no doubt real; whether killing the defendant relieves that terror is an open question. After Thomas Mason's execution in June 2000, his former wife (whose mother and grandmother were killed by Mason) told reporters, "I don't have to face the fear of this man hurting me anymore," but added, "I'm still nervous of this man even though he is dead." 13

9 Texas Executes Third Inmate This Year, Acence France Presse, Jan. 30, 2001, LEXIS, News Library, Afp File (internal quotation marks omitted).

10 Tim Hoover, Ardmoreite's Killer Executed, Tulsa WORLD, July 20, 2000, at A12 (internal quotation marks omitted).

11 For example, after John Wheat was executed in Texas in June 2001 for killing three children, their great aunt said of the children's mother-who was shot and brain damaged in the same attack-that "it may comfort her to know that he is dead and will not kill or harm anyone else." Texas Killer of Three Children Executed, UPI, June 13, 2001 (internal quotation marks omitted), LEXIS, News Library, UPI File; see also Fatal Injections End Lives of 2 Ark. Killers, Com. Appeal (Memphis, Tenn.), Sept. 9, 1999, at Al4 (discussing the execution of Mark Gardner); Killer Apologizes Before Execution, Dallas Morninc News, Apr. 4, 2001, at 22A (describing the execution of Jason Massey); infra note 18 (discussing Ricky McGinn's execution).

12 Texas Trooper's Killer Executed, UPI, Jan. 24, 2000, LEXIS, News Library, UPI File (internal quotation marks omitted).

13 Texas Convict Dies for Double Murder, UPI, June 12, 2000, LEXIS, News Library, UPI File (internal quotation marks omitted). 
More often, victims' families state their desire for a conclusion in abstract or metaphorical terms. Some of the relatives say that now, with the execution behind them, they can complete (or begin) the process of "healing". ${ }^{4}$ In eleven cases family members are quoted using the word "closure", and in another eight cases the news stories use the term but not in direct quotes. Some claim that the execution has provided "closure"; 15 others express confidence that it will come eventually, ${ }^{16}$ or that the execution is one step along the path; ${ }^{17}$ and some say that "closure" is impossible. ${ }^{18}$

Family members frequently refer to the execution as a conclusion-the end of a chapter, ${ }^{19}$ the end of a book, ${ }^{20}$ the closing of a

14 When Ronald Boyd was executed in April 2000 for the killing of an Oklahoma police officer, his victim's mother expressed the hope that "maybe we can heal and begin to go on with our lives." Bobby Ross, Jr., Murderer of City Police Officer Executed, Dally ORLAHOMAN, Apr. 27, 2000, at 1A (internal quotation marks omitted).

15 When Wilford Berry was executed in February 1999 after he waived his appeals in the slaying of Charles Mitroff, the victim's brother-in-law spoke for the Mitroff family, claiming, "At last we have closure ... . We feel no joy or satisfaction." Frank Hinchey, Victim's Family Can Now Move on with Life, Columbus Dispatch, Feb. 21, 1999, at 7D (internal quotation marks omitted). Others claim that the execution gave them some measure of peace without using the word "closure." When James Elledge was put to death in August 2001 for the murder of Eloise Fitzner, her brother expressed frustration with the attention paid to Elledge's decision to abandon his appeals, but also claimed that as a result of the execution " $[t]$ here's a sense that I can get on with my life." Gina Kim \& Janet Burkitt, Emotions Cooling Off After Execution, SEATtLE Times, Aug. 29, 2001, at B2 (internal quotation marks omitted).

16 After Alvaro Calambro's April 1999 execution in Nevada, the brother of one of his victims thanked the system for bringing Calambro to justice and said, "My closure will come later." Sean Whaley, Double Murderer Executed, Las Vegas Rev.J., Apr. 6, 1999, at 1A (internal quotation marks omitted). The father of another of Calambro's victims called it "the end of a very tragic affair," and said, "There is no elation, nothing like that. The law works. The law worked in our case." Id. (internal quotation marks omitted).

17 Walt Blatchford, the father of Sebastian Bridges's victim, is paraphrased in an article following Bridges's April 2001 execution as saying that "the execution was a step toward closure, but Bridges's death would not bring his son back." Sean Whaley, Inmate Executed for 1997 Murder, Las VegAs Rev.-J., Apr. 22, 2001, at 3A.

18 When Ricky McGinn was executed in September 2000 for the murder of his stepdaughter, her grandfather said, "I hate the word closure. I despise that word. There's never going to be any closure. ... But there's satisfaction. I am really satisfied he can't get out and kill any more little girls." Spared Twice, Texas Killer Executed, Deseret News (Salt Lake City, Utah), Sept. 28, 2000, at A2 (internal quotation marks omitted), LLX1S, News Library, Desnws File. After Paul Kreutzer's execution in Missouri in April 2002 for murdering Louise Hemphill, the victim's sister said, "l don't think there's ever closure . . . . There's still three kids that don't have a mother. There's still a man without a wife." Joe Strange, State Executes Man for Rape, Murder of Northeast Missouri Woman, AP, Apr. 10, 2002 (internal quotation marks omitted), WestLaw, AP WiresPlus File.

19 After Marlon Williams was executed for a contract killing in Virginia in August 1999, the victim's sister-in-law claimed that "[i]t closes a chapter." Contract Killer Executed in Va. After High Court Denies a Stay, WASH. Post, Aug. 18, 1999, at B3 (internal quotation marks omitted). The victim's son felt Williams had it easy compared with his mother's death. Id.

20 Following Earl Heiselbetz's January 2000 execution, Jim Whitton, the brother and uncle of Heiselbetz's two victims, "told reporters he was glad it was over. 'It was the last 
door ${ }^{21}$-rather than as a cure. For example, when Billy Hughes was executed in Texas in January 2000, Pat Teer, the mother of his victim, said she expected Hughes's execution to "close that chapter of life that has been so painful for our family," even if it did not relieve any of the pain of her son's death. ${ }^{22}$ "We have relived our worst nightmare over and over, instead of being able to remember happier things.... Twenty-four years is too long. I hope no one again has to go through it for 24 years." ${ }^{23}$

Many victims' relatives echo Ms. Teer's complaint. After William Burns's execution in Texas in April 2002, for example, the victim's brother said, "We've been dealing with this for 21 years. It's a load off of our shoulders to not have to worry about any more appeals, trials." ${ }^{4}$ John Weiler, husband and father of Allen Davis's three victims, expressed similar frustration following Davis's execution in July I999: "I've had to wait 17 years for some type of closure to this. No one else should have to do that. Any more than one year to [carry out] a sentence is ridiculous." ${ }^{25}$ Ending this painful process can become a major goal for the victim's family-sometimes the only realizable goal of the execution. When James Earhart was executed in Texas in August 1999, the mother of his nine-year-old victim said, "The only meaning this day has for me is that tomorrow I will not get a phone call ... that his conviction has been overturned and he's getting a new trial." 26

On the other hand, when James Elledge waived available appeals and was executed in Washington in August 200I for murdering Eloise Fitzner three years earlier, the victim's brother complained that "El-

chapter of a book,' he said. 'A bad book.'" Texas Killer Executed for Double Murder, UPI, Jan. 13, 2000, LEXIS, News Library, UPI File.

21 When Norman Newsted was put to death in Oklahoma in July 1999, the family of one of his victims issued a statement that "spoke of the I5 years they had endured the pain, anger and grief of his death," but said that "the execution "will close this door and allow the hurt to stop." Wire Reports, Dallas Morning News, July 9, 1999, at 38A.

22 S.K. Bardwell, End to Mom's Wait for Justice in Son's Murder May Be Near, Hous. Chron., Jan. 22, 2000, at A35 (internal quotation marks omitted).

23 Id. (internal quotation marks omitted).

24 Michael Graczyk, Convicted Killer Executed for 1981 Texarkana Slaying, AP, Apr. 11, 2002 (internal quotation marks omitted), WestLAw, AP WiresPlus File.

25 Beau Halton, Man Who Killed Three in '82 Put to Death, FlA. Times-Union, July 9, 1999, at A1 (alteration in original) (internal quotation marks omitted). Similarly, when Randal Hafdahl was executed in January 2002 for murdering a Texas policeman, his victim's family issued a statement saying, among other things, "Our family has had to endure I6 years of legal procedures that should never have been allowed to occur." Michael Graczyk, Convicted Texas Cop Killer Executed, AP, Feb. 1, 2002 (internal quotation marks omitted), WESTLAW, AP WiresPlus File.

26 Michael Graczyk, Killer of 9-Year-Old Girl Executed in Huntstille, Austin Am.-STatesMAN, Aug. 12, 1999, at B8 (alteration in original) (internal quotation marks omitted); see also Ben Tinsley, Arlington Teen's Killer Executed, Dallas Morning News, July 27, 2000, at Arlington Morning News IA (quoting the father after the execution of his son's killer: "I will never have to get up and look at a letter from yet another court, from yet another attorney, filing yet another appeal." (internal quotation marks omitted)). 
ledge's refusal to fight execution effectively 'short circuited' the process" of dealing with the emotional aftermath of the murder. ${ }^{27}$ This surprising reaction suggests that what matters most to families is not the length of time leading up to the execution, but instead what happens during that time. In some cases, repeated court dates stir up troubling memories of the murder and the victim's suffering. As the sister of one victim put it, "Every time there's another hearing, it's as if Timmy's corpse gets up out of the ground and walks into the courtroom. He truly has never been formally buried [and will not come to rest] until the case is closed one way or the other." ${ }^{28}$ She would have preferred a commutation over having to "relive her brother's death every time the case [came] up for another court review." 29 More often, the main problem is that the courts and the press repeatedly focus their attention on the defendant. In Elledge's case, for example, pre-execution press coverage was particularly heavy because Elledge willingly accepted his death for religious reasons. As a result, according to the victim's brother, "The normal healing process has been interrupted by this execution because the focus was on the perpetrator." 30

Victims' families frequently voice frustration with the attention the media pays to the defendants in capital cases. They complain about stories that report defenses that they believe are insulting to the victim, ${ }^{31}$ or that describe mitigating factors such as remorse, low I.Q., or a history of child abuse. ${ }^{32}$ For one, they believe that these stories

27 Rebekah Denn \& David Fisher, Execution Leaves a Trail of Unease, SEATtLE PostINTELLIGENCER, Aug. 29, 2001, at Al.

28 Death Penalty Taking Its Toll, WASH. Post, June 12, 2002, at B1 (internal quotation marks omitted).

29 Id.

30 Kim \& Burkitt, supra note 15 (internal quotation marks omitted).

31 Although James Beets, the son of Betty Beets's victim (and Beets's stepson) said he forgave her, see infra text accompanying note 93 , he was angry at the wide coverage given to her claim that the victim physically abused her: "My dad was a Dallas fireman for 26 years. He lived to help people, not hurt them. It was wrong of her to tarnish his name. I just hope that the people know and they can see that my dad was a good man." Sarah Chalmers, The Black Widow of Death Row Is Executed, Dalty Mall (London), Feb. 26, 2000, at 46 (internal quotation marks omitted). After James Moreland's execution, the victim's brother was angry at Moreland's "gay panic" defense: "My brother was by no means a homosexual. I know this for a fact. ... Neither was [the other victim]. He'd have fought you if you even mentioned it to him." Man Executed for '82 Slaying, SAN ANTONIO Express-News, Jan. 28, 2000, at 3B (internal quotation marks omitted).

32 After Marlon Williams was put to death in August 1999 for the 1993 contract killing of Helen Bedsole, her fanily attacked his defense that he had been the victim of child abuse. Bedsole's sister-in-law said, "This excuse of abuse is just unreal. There are millions of adults out there who were abused and who never killed anybody." Contract Killer Executed in Va. After High Court Denies a Stay, supra note 19 (internal quotation marks omitted). Her daughter said, "I'm sorry that [Marlon] had such a bad childhood, but for the last six years what me and my brother went through would not excuse us to go out and kill somebody ... . He's getting what he deserves." Id. (internal quotation marks omitted). 
make the defendants look too good. Thus, when Darrell Rich was put to death in California in March 2000, the brother of one of his four murder victims said that "he was sick of reading newspaper stories quoting Rich's lawyers saying the condemned man was remorseful. 'He was sorry, sorry that he got caught'. . . . 'Darrell Rich is not the victim in this story. He was the cause of this all." "33 At the same time, they are also angry because the focus on the defendant's misfortunes distracts attention from the real victims. For example, after Wanda Jean Allen's execution in January 2001, the niece of one of the victims criticized the media for its coverage of a campaign for clemency based on Allen's low I.Q.: "You guys feel sorry about Wanda Jean, but your concern should be with the families . . . . We are the victims." 34

For some surviving family members, the execution is an opportunity to attempt to redress this imbalance. When Kelly Rogers was executed in March 2000 for the murder of twenty-one-year-old Karen Lauffenburger, her parents distributed a letter written by her mother that explained, "To our misfortune, you never knew our Karen . . . . By this letter, I hope to give you a small picture of this girl we were proud to call daughter and what her life was like before Rogers ended it that December."35 Lori Bruch's family clearly expressed the hope behind this gesture in their press statement: "Today is finally the day for this victim." 36 More often, however, the function of the execution for the victim's relatives is merely negative. As the brother of one of Sean Sellers's three murder victims said after Sellers was executed in February I999: "I am relieved knowing the next day or two will take him off television, out of the newspaper and into the past." 37

\section{B. Justice and Vengeance}

About one-fourth of our stories report that the victims' families said, usually without elaboration, that "justice was done" by the execution. For example, the brother of James Robedeaux's victim said after Robedeaux's execution in Oklahoma in June 2000, "I can't really say

\footnotetext{
33 J. Harry Jones, Slayer's Own Death 'Too Easy', SAN Diego Union-Trib., Mar. 16, 2000, at A3.

34 Bobby Ross, Jr., Wanda Jean Allen Executed, Daily Oklairoman, Jan. 12, 2001 (internal quotation marks omitted), LEXIS, News Library, Dlyokn File.

35 Scott Cooper, OSU Siudent's Killer Is Put to Death, Tulsa WorLd, Mar. 23, 2000 (internal quotation marks omitted), LEXIS, News Library, Tlswld File.

36 Texas Executes Third Inmate This Year, supra note 9 (internal quotation marks omitted).

37 Barbara Hoberock \& Julie Delcour, Sellers Paid 'Full Price', Tulsa World, Feb. 5, 1999 (internal quotation marks omitted), LEX1S, News Library, Tlswld File; see also Steve Mills \& Rick Pearson, Texas Executes Graham, CIII. TRıв., June 23, 2000, at 1 (reporting murder victim's ex-wife's statement about defendant: "His death . . . would finally spare the family the renewed pain of repeatedly seeing the televised image of the slain man lying under a sheet, juxtaposed with Graham . ....").
} 
I'm happy to see him die, but justice was carried out."38 A few family members say that they hope or expect that the execution will deter other killings. The brother of Emerson Rudd's victim had a clear position on this issue: "If the state did not carry out the execution, what do you think criminals would do? ... This serves as a deterrent." 39 More often, the relatives are hopeful but less certain. When Joseph Faulder was executed in June 1999 for murdering Inez Phillips, the victim's son issued a statement: "Now that the proper sentence has been carried out, our family can take some measure of comfort in knowing that justice has been done, and we hope that the carrying out of this sentence will be a deterrent to other brutal crimes." 40 And when Abdullah Hameen was executed in Delaware in May 2001, his victim's sister said, "I hope this deters anybody who wants to commit a murder."41

Most of those who speak of justice, however, seem to view the execution in more abstract terms-as an appropriate form of retribution. The statement released by Ralph Childress's family after the September 2001 execution of Ronald Frye in North Carolina, for example, talks about the execution as a necessary response to a horrific crime: "The family of Ralph Coburn Childress deeply regrets that the action [that] was taken here tonight was a necessary part of our justice system. It was carried out not to avenge the victim but to punish the guilty." 42 Others, such as Glenn Williams, whose brother was one of Gerald Tigner's two victims, see the execution as an impressive accomplishment that vindicates a judicial process that is so often criticized as slow and untrustworthy: "The system does work and this is proof that it does work." 43

In an overlapping group of about one-fourth of these stories, the victims' families discuss the executions in the more personal terms of revenge. These survivors fall into two broad categories: those who are satisfied with the killer's death, and those who feel that he should have suffered more. When Leslie Martin was executed in May 2002 for raping and murdering nineteen-year-old Christina Burgin, for ex-

38 Jay Grelen, Oklahoma Executes Inmate for Woman's 1985 Murder, Daily OkLAHOMAN, June 2, 2000, at 10A (internal quotation marks omitted).

39 Michael Graczyk, Dallas Restaurant Manager Killer Executed, AP, Nov. 16, 2001 (internal quotation marks omitted), WestLaw, AP WiresPlus Files.

40 Maro Robbins, State Executes Canadian for Slaying During Burglary, SAN ANTonio ExPRESS-News, June 18, 1999, at 7B (internal quotation marks omitted).

41 Randall Chase, Killer Who Claimed Rehabilitation Executed in Delaware, AP, May 25, 2001 (internal quotation marks omitted), WESTLAW, AP WiresPlus File.

42 Anne Saker, Despite Questions About Defense, Frye Executed for Killing Landlord, NEws and Observer (Raleigh, N.C.), Sept. 1, 2001, at 3A (alteration in original) (internal quotation marks omitted).

43 Waco Man Executed for 1993 Shootings, AP, Mar. 8, 2002 (internal quotation marks omitted), Westlaw, AP WiresPlus File. 
ample, the victim's mother said at a post-execution news conference, "I'm ecstatic. I'm happy." 44 Her father added, "My smile says it all."45 Similarly, after the March I999 execution of Robert White, who had served nearly twenty-five years on Texas's death row for three murders, the brother of one of his victims said, "I enjoyed watching the man die. I really did."46 A few relatives say they would like to have done the killing themselves. Nathan Hill, twin brother of Edward Castro's victim, said on the eve of Castro's execution: "I'm just glad the S.O.B.'s dying .... And I'd like to take my shotgun and take a shot." 47

Among those who want the killer to suffer more, many believe that lethal injection is too quick and painless. They generally talk of the process as "going to sleep" or "being put to sleep." For instance, when Clifton White was put to death in August 200I for murdering twenty-eight-year-old Kimberly Ewing, her sister was unsatisfied: "The penalty has been carried out, but this is by no means justice . . . He went to sleep. Kim suffered a violent death. His family had over 12 years to say goodbye to him. We were robbed of that luxury." 48 Janet Salais, sister of the man Joseph Parsons stabbed to death, had a similar point of view: "I believe in an eye for an eye," which she believes would have been achieved if Parsons had died in "the same manner that he killed my brother." 49 And the victim's widow said, "Richard was brutally murdered. Parsons was just anesthetized, put to sleep, it is not the same." 50

A handful of relatives say they oppose execution because it is an insufficient form of revenge, or because it will cut short the murderer's suffering. ${ }^{51}$ Twyla Alvarez, for example, the daughter of a fiftytwo-year-old man who was murdered by John Romano and David Woodruff, opposed their execution in part because "John Romano is no longer able to suffer the guilt and remorse I hope he felt every day

44 James Minton, Condemned Killer Meets Death, Extends No Apology to Family, Saturday State Times/Morning Advocite (Baton Rouge, La.), May 11, 2002, at 1A (internal quotation marks omitted).

45 Id. (internal quotation marks omitted).

46 Bruce Tomaso, 'Send Me to My Maker, Warden', Dallas Morning News, Mar. 31, 1999, at 23A (internal quotation marks omitted).

47 Kathryn Wexler, Murder Victim's Twin Says Anguish Endures, ST. Petersburg Times, Dec. 7, 2000, at 1B (internal quotation marks omitted).

48 Clifton White Executed for Murder of Woman, News \& Observer (Raleigh, N.C.), Aug. 25, 2001, at 3A (internal quotation marks omitted).

49 Jennifer Dobner, 'Morbid' or 'Justice'? Reactions Vary, Deseret News (Salt Lake City, Utah), Oct. 15, 1999, at A7 (internal quotation marks omitted).

50 Amy Joi Bryson, Parsons Gets His Death Wish, Deserer News, Oct. 15, 1999, at A1 (internal quotation marks omitted).

51 When Thomas Akers waived appeals and was executed in February 2001 for murdering twenty-four-year-old Wesley Smith, a news article reported that "Smith's family isn't sure the death penalty is enough punishment, if that's what Akers wants." Matt Chittum, State Supreme Court Denies Motion for Stay of Thomas Akers' Execution, Roanoke Times \& World News, Feb. 28, 2001, at B1. 
that he lived behind bars. I don't see that anything has been gained." ${ }^{2}$ This reaction might reflect a general opposition to the death penalty rather than a real desire to inflict further pain on the killers. Thus, after Woodruff's execution, Ms. Alvarez "said she felt the same way even though Woodruff made no pretense of feeling remorse. 'He got off too easy,' she said." 53

For others, worldly suffering of any sort is insufficient, but their religion holds out hope that God will truly punish the murderers. For example, after Byron Parker was executed in Georgia in December 2001, the mother of the eleven-year-old girl Parker murdered said, "He took everything away from me, and I hope he burns in hell." 54 Similarly, when Mark Fowler and Billy Fox were put to death in January 2001 one victim's half-brother told the media that "[s]ometimes, literally, the wage of $\sin$ is death," ${ }^{55}$ and the brother of another victim issued a statement requesting "all people of good conscience to pray for the souls of the three victims . . . as well as pray that the souls of these two killers be sent directly to Hell." 56 Some relatives have no doubt that divine retribution will be forthcoming. When Robert Carter was executed in Texas in May 2000 for murdering his four-yearold son and five other people, the boy's mother's family released a statement that read in part, "Our family may move one step closer to healing just by knowing Robert Carter will suffer a real and true punishment after death by the hand of God." 57

\section{Compassion}

About $10 \%$ of the stories report that members of the victims' families expressed compassion for the defendants or, more often, for the defendants' families. Sometimes the sentiment is formal and perfunctory. When Troy Farris was executed in January 1999, the victim's father said, "I feel sorry for the boy who is receiving the punishment .... But he killed my boy, and he deserves it." 58 In other cases, the sentiment appears genuine and powerful. The widow of Lynda Block's victim, for example, was so overcome with emotion that she

52 Ginnie Graham, Accomplice Is Put to Death, TulsA World, Feb. 1, 2002, at A16 (internal quotation marks omitted).

53 Graham Underwood, Second Man Executed for Oklahoma City Killing, AP, Feb. 1, 2002, Westlaw, AP WiresPlus File.

54 Rhonda Cook, Parker Executed Despite Advocates' Pleas for Mercy, Atlanta J. \& Const., Dec. 12, 2001, at B3 (internal quotation marks omitted).

55 Mass Killer Executed in Oklahoma, UP1, Jan. 25, 2001 (internal quotation marks omitted), LEXIS, News Library, UP1 File.

$56 \quad I d$. (internal quotation marks omitted).

57 Ex-prison Guard Executed for Slayings, UP1, May 31, 2000 (internal quotation marks omitted), LEX1S, News Library, UP1 File.

58 Michael Graczyk, Texas Executes Inmate for Deputy's 1983 Slaying, Austin Am.-STAtesMAN, Jan. 14, 1999, at B2 (internal quotation marks omitted). 
asked to leave the death chamber just before the execution. ${ }^{59}$ Noting that Block had no family or friends present, the victim's widow said, "It seems to me that no one cared . . . . I feel very sorry for her. It must have been a very lonely time that she spent in prison." ${ }^{60}$ Similarly, although relatives of Manuel Babbit's victim distributed a statement saying that justice had been served by his execution, they added that their "hearts and prayers go out to the Babbitt family. We know how much they have suffered." 61

Concern for the killer is usually expressed in religious-to be specific, Christian-terms. When Jose High was put to death in November 2001, the mother of the eleven-year-old boy he killed twenty-five years earlier said, "I really hope God forgave him. I really hope someday that I will have the strength to do that." 62 The family of Jerald Harjo's victim said much the same thing in a written statement released after his execution: "We hope that Jerald Harjo has given his life to Jesus and has asked for forgiveness." 63

\section{Clemency and Intrafamilial Conflict}

Only ten of our cases (about 7\%) mention that a victim's family member supported clemency for the defendant. On this issue, however, our collection is likely to be especially unrepresentative for two reasons. First, if the execution does occur, family members who favor clemency are unlikely to attend, ${ }^{64}$ and probably equally unlikely to release statements or talk to the media. Second, when the victim's family is united in opposing execution, they are likely to prevail, and there will be no execution for us to study-especially if they make their views known in the early stages of the legal process and the defendant is never charged with capital murder in the first place.

Not surprisingly, in seven of these ten cases the press stories also describe a conflict within the victim's family. The most striking example is the execution of Floyd Medlock in Oklahoma in January 2001 for the brutal murder of seven-year-old Kathy Busch. Kathy's two

59 Dave Bryan, Widow Feels Sorry for Husband's Killer, Charleston GazetTe, May 11, 2002 , at $8 \mathrm{C}$.

$60 \quad I d$. (internal quotation marks omitted).

61 Maria L. La Ganga, Executions Eliciting a Growing Indifference, L.A. Times, May 5, 1999, at A3 (internal quotation marks omitted).

62 Erin McClam, State Executes Convicted Killer, AP, Nov. 7, 2001 (internal quotation marks omitted), WESTLAW, AP WiresPlus File.

63 Jasen Corns, Man Executed for Killing Sasakwa School Worker, Tulsa WorLd, July 18, 2001, at LEXIS, News Library, Tlswld File.

64 All of the stories that mention that family members advocated clemency refer to statements that were made before the execution. In only one such case do the stories report that a victim's relative who supported clemency attended the execution. See infra notes 65-72 and accompanying text (discussing Johnnie Cabrera's opposition to Floyd Medlock's execution, which she attended). 
grandmothers became active spokeswomen on opposite sides of the death penalty debate: one, Judy Busch, as founder of the Survivors of Homicide Support Group; the other, Johnnie Cabrera, as chairwoman of the Oklahoma Coalition Against the Death Penalty. ${ }^{65}$ At the time of the execution, the two women had not spoken "since a 1992 confrontation inside the Oklahoma Capitol, where Ms. Cabrera was speaking against capital punishment and Ms. Busch rebuked her. 'We can't sit in the same room,' said Ms. Cabrera."66 Ms. Cabrera said she opposed Medlock's execution because of religious beliefs ${ }^{67}$ and because she did not understand what it would accomplish. ${ }^{68}$ "When we kill him, all he's going to do is go to sleep. I think he should sit in his prison cell the rest of his life and think about what he's done."69 Ms. Busch, however, said that for ten years she "dealt with the possibility that some court or some judge or someone would overturn [his] sentence and he would be out .... When he's executed ... I won't have that worry."70 Ms. Cabrera complained that she was "shut out of the family's life because Ms. Busch was so 'controlling." "71 In Ms. Busch's view, however, "Ms. Cabrera was simply indifferent and uninvolved in the lives of her daughter, Gina, and granddaughter, Kathy." 72

Except in the most extreme cases, these sorts of disputes are not aired in public. Not surprisingly, none of the other cases that report divisions among family members over clemency includes any information on the effect of that conflict on the family. We suspect that what we can retrieve from published stories is just the tip of an iceberg. After the execution of Randal Hafdahl in February 2002, the victim's family issued a statement celebrating the fact that " $[t]$ onight Hafdahl was forced to confront a family that is intact, strong and unbending in our resolve to see his punishment carried out."73 Other victims' families undoubtedly work to maintain a similar appearance of solidarity, not only to impress the defendant but for public consumption and their own self-image as well. If the defendant is in fact executed, that

65 See Arnold Hamilton, Life and Death: Granddaughter's Murder Divides 2 Women on Capital Punishment, Dallas Morning News, Jan. 15, 2001, at 1A.

$66 I d$.

67 " $[\mathrm{H}]$ er Presbyterian upbringing, Ms. Cabrera said, also left her with the conviction that 'only God has the right to take a life. He put us here, and he's the only one who can take us away." Id.

68 "Executing [Medlock] is not going to close this thing. What does it accomplish? All you're doing is making another family suffer grief." Id. (internal quotation marks omitted).

69 Id. (internal quotation marks omitted).

70 Id. (internal quotation marks omitted).

71 Id.

$72 I d$.

73 See Graczyk, supra note 25 (internal quotation marks omitted). 
means that family members who oppose the execution must hold their peace.

\section{E. Intrafamilial Killings}

More than I3\% of all murders in the United States are committed by members of the victims' families. ${ }^{74}$ These cases are underrepresented in our sample of murders that led to executions-only 10 of $\mathrm{I} 38$ (about $7 \%$ ) involve killings by family members ${ }^{75}$ - which probably reflects the fact that murders by strangers are generally considered more aggravated. ${ }^{76}$ Ten is too small a number of cases for confident generalizations, but even so there is a striking division between those relatives of the victims who are related to the defendant by blood and those who are related to the defendant by marriage.

On one side, those who are related to the defendant by marriage only are unforgiving. Thus, for example, after Ronald Fluke was executed in Oklahoma in March 2001 for murdering his wife, Ginger, and their two daughters, Ginger Fluke's family read a statement:

"Most people lock their doors at night to keep the bad guys out. Little did they know that dreadful night they were locking the bad guy in. He not only took the lives of three very precious people, he also took a part of many others who loved Ginger, Susanne and Kathryn very, very much . ..."77

And when Robert Carter was executed for killing his four-year-old son and five other people, the family of the boy's mother was succinct: "This is not a joyous occasion by any means. Our family may move one step closer to healing just by knowing Robert Carter will suffer a real and true punishment after death by the hand of God."78

On the other side, relatives who were related by blood to both the killer and the victim have more complex reactions. For the most part, they focus on the trauma of the event rather than on blame or punishment. For example, when Jeffrey Caldwell was executed for murdering his parents and sister, one of his brothers said, "There's still a lot

74 In 2000, the relationship of the victim to the killer was known in $57.4 \%$ of the I2,943 murders for which information was available to the FBI, and in $13.4 \%$ of these cases the killer and victim were members of the same family. See U.S. Dep't of Justice, CRIme in THE United States 2000, at 2 I fig. 2.7 (2000). In 1999, the comparable proportion was 13.8\%. See U.S. Dep't of Justice, Crime in the United States 1999, at 20 fig.2.7 (1999).

75 We did not count the many murders in which the murderer was involved in a sexual relationship with the victim or a member of the victim's family, but was not otherwise related. We also did not count two contract killings arranged by an estranged husband, in which the actual killer, rather than the husband, was executed.

76 See Samuel R. Gross \& Robert Mauro, Deathi and Discrimination 56-57 (1989).

77 Danny M. Boyd, Man Executed for Killing Family, Daily OKL.homan, Mar. 28, 2001, at $4 \mathrm{~A}, 2001 \mathrm{WL} 14517495$.

78 Exprison Guard Executed for Slayings, supra note 57 (internal quotation marks omitted). 
of unanswered questions .... There's still a feeling of loss, a feeling of despair. I can't change what happened. I can't change what he did. I can just pray that after this lifetime is over, I'll fully understand what really happened."79 Mr. Caldwell's brother was speaking off the cuff, but even the prepared statements that are more common in these situations are generally ambivalent. For example, after Robert Coulson was put to death for murdering five members of his family, including his biological sister and adoptive parents, the family released a statement: "This unspeakable tragedy has forever altered my life and the lives of my extended family .... While our grief is incalculable, we are comforted by our deep and abiding faith in God and our belief in the justice system." 80 The most unambivalent statement by blood relatives of the defendant is in a case in which they opposed execution. After Fred Gilreath was executed for the murder of his wife and father-in-law, his two children issued a statement through a spokesperson who said that the family was "devastated," and that "[t]he state of Georgia made orphans of [the two children] . . . despite their pleas to the state of Georgia that their families not be traumatized. Another body is in the coffin." ${ }^{11}$

\section{F. Apology and Forgiveness}

Execution stories almost inevitably describe the executed person's final words or mention their absence. In 40 of our 138 cases the stories report that the defendants apologized for the killings; in 13 other cases family members expressed anger or disappointment that the killer offered no apology; and in several additional cases the stories mention that although the defendant had no final words, he previously apologized to the victim's family or expressed remorse. ${ }^{82}$ Like closure, justice and vengeance, apology is one of the issues most frequently discussed in the execution stories we have collected; unlike them, apology is within the control of the condemned prisoner.

In some cases the victim's relatives are clearly moved by the killer's request for forgiveness. Marguerite Hensley, for example, the widow of a liquor store owner killed by James Richardson during a 1986 robbery, told reporters she was glad she decided to attend the

79 Dallas Man Executed for Triple Murder, UPI, Aug. 30, 2000 (internal quotation marks omitted), LEXIS, News Library, UPI File.

80 Michael Graczyk, Man Convicted in Slayings of Family Members Executed, AP, June 25, 2002 (internal quotation marks omitted), WESTLAW, AP WiresPlus File.

81 Rhonda Cook, Gilreath Executed as Stays Run Out, Atlanta J. \& Const., Nov. I6, 2001, at D1 (internal quotation marks omitted).

82 Alvie Hale, for example, did not seek forgiveness in his last words, but his victim's sister, who had met with Hale repeatedly over the six years leading up to the execution, said, "I forgave Jim Hale a long time ago, but forgiveness doesn't mean I condone what happened. Forgiveness lets you get on with your life." Jeff Martin, Killer Gets Mercy from Victim's Kin, Tulsa WORLd, Oct. 19, 2001, at A12 (internal quotation marks omitted). 
execution because "[i]t was worth it to hear him say, 'forgive me." " 83 And Emilie Pearson, mother of one of Gary Walker's victims, was surprised by Walker's last-minute apology: "The words helped, whether he meant them or not ...." 84

These cases, however, appear to be uncommon. We found explicit statements accepting an apology in only 8 of our 138 executions. About twice as often the victims' relatives doubt the apology ${ }^{85}$ or reject it outright. Mary Atkin, the sister of one of John Castro's victims, "didn't think Castro's remorse came from the heart. 'I was not touched.' . . . But as a Christian, Atkin said she accepted Castro's apology." 86 The daughter of Dion Smallwood's victim was more pointed: "His apology meant nothing." 87 More often yet, the victim's relatives say nothing at all in response to the killer's apology, or at least nothing that was picked up in the articles that we have found. And in over a dozen cases, family members were angry or dissatisfied because the killer failed to apologize or express remorse. When Terrance James died without a word, his victim's sister was disappointed: "I had hoped for an apology .... . It would have been easier on all of us." 88 Similarly, when Jessy San Miguel was put to death, Mary Gomez, the mother of one of his four victims and the aunt of another, felt hurt because, "[h]e didn't even look at us. . . He showed no remorse." 89 The strongest (and longest) public reaction of this sort came from a politician, Ken Chlouber, nephew of Loyd LaFevers's victim and a Colorado state senator: "LaFevers has never shown one degree of remorse, not one iota, not one bit of sincere regret. . . You would have thought he would apologize to God . . . to get some degree of forgiveness." 90 According to Chlouber, LaFevers's last words were "incredibly insulting to the family, to all the victims." 91

83 Texas Killer Repents Before Execution, UPI, May 23, 2000 (internal quotation marks onitted), LEXIS, News Libraly, UPI File.

84 Linda Martin, Walker's Apology Surprises Relatives, Tulsa World, Jan. I4, 2000, at A9 (internal quotation marks omitted).

85 See, e.g., James Kimberly, Killer Admits Guilt in Death Chamber, Hous. Chron., Mar. 8, $200 \mathrm{I}$, at A23 (reporting that the victims' mother wanted to believe Dennis Dowthitt's preexecution apology was sincere, but had her doubts), LEXIS, News Library, Hehrn File.

86 Manny Gamallo, Condemned Killer Questions Next Execution, Tulsa WorLd, Jan., 8,

I999, LEXIS, News Library, TIswld File. A son of Castro's other victim also disbelieved Castro's expressions of remorse. Id.

87 Thomas Mullen, Daughter of Murder Victim Ignores Apologies from Condemned Killer, AP, Jan. 19, 2001 (internal quotation marks omitted), WestLaW, AP WiresPlus File.

88 Brian Barber \& Ty McMahan, State Completes /2th Execution, Tulsa World, May 23, 2001 (internal quotation marks omitted), LEXIS, News Library, Tlswld File.

89 Texas Executes Confessed Killer of Four, UPI, June 29, 2000 (internal quotation marks omitted), LEXIS, News Library, UPI File.

90 Howard Pankratz, Leadville Senator Witnesses Execution of Aunt's Killer, Denv. Post, Jan. 31, 2001, at B1 (internal quotation marks omitted).

91 Id. (internal quotation marks omitted) (reporting LaFevers's last words as including thanks to his family and loved ones, but not an apology to the victim's family). 
The other side of the coin from apology is forgiveness. In this context, forgiveness is an explicitly religious concept. Those few relatives who claim to have forgiven the killer invariably mention God. After Jermarr Arnold's execution, for example, his victim's mother said, "He's a human being and we need to forgive .... . Let God take care of him." 92 And after the execution of Betty Beets, the son of one of her victims said, "I forgive her, I ask God to forgive her and that's just the way I feel in my heart." 93 Outright expressions of forgiveness appear in only half a dozen of these cases. About twice as often relatives say they hope to be able to forgive the defendant some day, but have not reached that point yet. For example, Emilie Pearson, who was touched by Gary Walker's apology for killing her daughter, said, "At some point, I hope I'll be able to [forgive him]. . . . For my sake, I'd like to be able to forgive him. I know it would help me tremendously." ${ }^{4}$ But her immediate reaction to the execution was more vengeful: "This is too easy. He murdered five people. . . . They suffered. All he did was lay there and go to sleep ... I know that sounds cruel for me to say, but it was just too easy for the crimes he did . . . "95 Similarly, after Lois Smith was executed in Oklahoma, her victim's daughter "said she hopes one day to be able to forgive Smith, but that day may be far off." 96

If everything falls into place, the combination of apology and forgiveness can produce an event that some surviving relatives find very moving. The full-blown version-what one might call a "Hallmark execution"-has the following elements: (1) The condemned killer looks directly at the victim's family, accepts responsibility for his crimes and apologizes to them honestly and sincerely; (2) the family accepts the apology and forgives him; (3) the killer achieves peace and (presumably) is reconciled to God; and (4) the killer is put to death. A few executions approach that ideal. Feltus Taylor, for example, in his final statement, told the family of his victim and a surviving victim who was partially paralyzed, "I've always regretted what I've done ... it was always my own doing." 97 After his death, the surviving victim said, "I saw a man go to heaven tonight, I do believe." 98 And before the execution of Pernell Ford for the June 1983 murder of

92 Michael Graczyk, Convicted Killer with Volatile Past Put to Death in Texas, AP, Jan. 17, 2002 (internal quotation marks omitted), WESLAW, AP WiresPlus File.

93 Chalmers, supra note 31 (internal quotation marks omitted).

94 Martin, supra note 84 (second alteration in original) (internal quotation marks omitted).

95 Id. (internal quotation marks omitted).

96 Bob Doucette, Woman Executed for 1982 Murder, Dally OkLaHoman, Dec. 5, 2001, at 4A, 2001 WL 30086766.

97 Michelle Millhollon, Taylor Put to Death, The Advocate (Baton Rouge, La.), June 7, 2000, at $1 \mathrm{~B}$ (alteration in original) (internal quotation marks omitted).

98 Id. (internal quotation marks omitted). 
Wayne Griffith's mother and sister, Mr. Griffith said he would be able to forgive Ford " $[w]$ hen they pull the lever." ${ }^{9}$ After Ford apologized and was executed, Mr. Griffith said, "It's finished ... . I do forgive him. I hope he's gone to heaven." 100

Such scenes are rare. In some cases the obstacle is the victim's family: they reject the apology outright, have no reaction to it, or want to forgive the killer but are unable. The fundamental problem, however, is on the other side: in the drama of apology and forgiveness, the murderer is the central character, and he may not play along. If he does not, the execution is likely to be frustrating or painful for those family members for whom an apology is an important goal. Judging from these stories, most defendants who are executed do not apologize. ${ }^{101}$ For example, after Gerald Casey's execution in April 2002, his victim's mother said, "It bothers me he didn't show any remorse. I will never be able to forgive him now." 102 She added, "I wanted to see him suffer," and that the execution had been "very extremely disappointing" for her and her family. ${ }^{103}$ And the widow of one of Miguel Richardson's victims was dubious of claims that he had undergone a religious conversion in prison: "He must believe in a different God or he would have asked us to forgive him ...."104 The other victim's son decided not to attend the execution precisely because he realized that Richardson might remain unrepentant: "I wanted to hold fast to forgiveness .... If someone doesn't do or say what you hope they will, they get the last laugh."105

Even when the actual event is satisfactory, the uncertainty and anxiety that precede the execution can take their toll. Before he was executed for murdering Patricia Webb, William Kitchens spoke to Webb's family: 'I'm so sorry I don't know how to tell you. I'm sorry. I hope you can move on and find peace in your life. The Lord has

99 Ashley Estes, Apology Before Execution Believed, Chattanooga Times, June 3, 2000, at B8 (internal quotation marks omitted).

$100 \quad I d$. (internal quotation marks omitted).

101 In fact, in very few cases the condemned person's final statement was defiant or deliberately hurtful. For example, Joseph Parsons's final words were "the rainbow warrior rules," which was apparently a reference to his claim that the victim had made a homosexual pass at him. Bryson, supra note 50 (internal quotation marks omitted). The victim's sister expressed her disappointment that Parsons did not suffer enough, while the victim's widow "was not surprised at Parsons's last disparaging remark directed at her former husband, adding she never expected to witness any remorse by the killer. . . . 'I don't feel sorry for him .... I think Joseph Parsons decided his fate when he stabbed Richard the very first time." "Id.

102 Michael Graczyk, Convicted Killer in Gun Burglary Heads to Texas Death Chamber, AP, Apr. 19, 2002 (internal quotation marks omitted), WESTLAw, Allnewsplus File.

103 Id. (internal quotation marks omitted).

104 Lisa Sandberg, 'Good Day to Die' for Richardson, SAN Anronio Express-News, June 27, 2001, at $1 \mathrm{~A}$ (internal quotation marks omitted).

105 Lisa Sandberg, Ex-pimp's Execution Scheduled Tonight, SaN ANTonio Express-News, June 26, 2001, at 1A (internal quotation marks omitted). 
given me peace. I'm sorry for what I did."106 The victim's husband was pleased: "He accepted responsibility. He said he was sorry. $\mathrm{He}$ showed remorse . . . [I]t was comforting to me . .."107 But the process that led up to that point left him bruised and wary. When asked what advice he would give to other families in future executions, the victim's husband said, "I guess just be prepared for anything. You never know what they will say or do."108

\section{II}

\section{EXONERATIONS}

Sometimes the cases of defendants who were sentenced to death end not in execution but rather in exoneration. The Death Penalty Information Center lists 102 defendants who have been released from death row since 1973 because of convincing evidence that they are innocent, ${ }^{109}$ more than 1 exoneration for every 8 executions over the same period. ${ }^{110}$ We have found stories that refer to statements by the victims' families for 34 cases of these exonerated death row defendants. Eight of those exonerations, however, occurred in multiple-defendant cases with 2 defendants each, leaving 30 discrete cases. ${ }^{111}$ We excluded 3 additional cases in which the defendants were convicted of killing members of their own families, because these cases made the position of the surviving family members-who were related to both the exonerated defendants and the dead victims-more complex and fundamentally different from that of the families in the remaining 27 cases. ${ }^{112}$

The exoneration of a death row inmate can take various forms. Sometimes the state admits the error and dismisses the charges or grants the defendant a full pardon. ${ }^{113}$ In other cases state officials (or

106 Oklahoma Man Executed for Texas Murder, UPI, May 9, 2000 (internal quotation marks omitted), LEXIS, News Library, UPI File.

107 Id. (internal quotation marks omitted).

108 Jason Gibbs, Execution Witness Offers Advice, Scripps How. News Serv., May 24, 2000

(internal quotation marks omitted), LEXIS, News Library Schwrd File.

109 See Dealth Penalty Info. Ctr., Innocence and the Death Penalty, at http://www. deathpenaltyinfo.org/innoc.html (last visited Nov. I0, 2002).

110 There have been 805 executions in the United States since 1976. See Death Penalty Info. Ctr., supra note 6 .

111 See Death Penalty Info. Ctr., Cases of Innocence 1973-Present, at http://www. deathpenaltyinfo.org/innoccases.html (last visited Nov. I0, 2002).

112 Id.

113 For example, on April 29, 2002, the prosecution asked an Arizona County Superior Court judge to dismiss the charges against Ray Krone, who had been sentenced to death and spent more than ten years in prison. Jyothi Sampat, Judge Dismisses Charges Against Man Cleared by DNA, AP, Apr. 29, 2002, WESTLAW AP WiresPlus File. And in October 2000, Virginia Governor James Gilmore granted an absolute pardon to Earl Washington, Jr., who had been in prison for seventeen years on a capital murder conviction. Frank Green, In mate May Wait till February, Rich. Times-Dispatch, Oct. 5, 2000, at B1. Both Krone and Washington were cleared by DNA evidence. 
some of them) continue to argue that the defendant is guilty, but the defendant is released because charges are dismissed by a court ${ }^{114}$ or by the prosecution after an adverse court ruling ${ }^{115}$ or a mistrial, ${ }^{116}$ because the defendant is acquitted at a retrial, ${ }^{117}$ or because the defendant pleads guilty to second-degree murder as part of a deal that includes credit for time served and immediate release. ${ }^{118}$ One defendant was exonerated after he died in prison of cancer."19 The physical process of releasing a defendant, like the means of exoneration, is also extremely variable and rarely as well-scripted as an execution. Some defendants are freed in open court by direct order of the judge. ${ }^{120}$ One defendant who was waiting to find out if he would be retried was literally taken to the gate without warning and pushed into the street. ${ }^{121}$ News coverage of these events is less predictable than coverage of executions, but, even so, the stories tend to include refer-

114 For exanple, the Illinois Supreme Court ruled in 1999 that the prosecution had not met its burden of proof in Steven Snith's murder trial, reversed the conviction, and barred the state from retrying the case. Ken Armstrong \& Todd Lighty, Death Row Conviction Thrown Out, CH1. TriB., Feb. 20, 1999, at 1. The Illinois State's Attorney's office said they "respectfully disagreed with the Supreme Court's decision." Id.

115 In Ricardo Guerra's case, for example, the district attorney dismissed the charges after a judge ruled that the state could not use at retrial six witnesses whose testimony was tainted by police or prosecutorial misconduct at trial. Jo Ann Zuñiga, Charges in ' 82 Police Slaying Are Dismissed, Hous. CHRON., Apr. 16, 1997, at 1A.

116 In February 1998, for example, the district attorney reluctantly dropped the charges against Curtis Kyles after prosecutors failed to convince a jury of Kyles's guilt after their fifth attempt to do so. After an initial mistrial, Kyles was convicted in I984 for murdering Delores Dye. Kyles's conviction was set aside by the U.S. Supreme Court in 1995, and prosecutors retried Kyles three times over the next three years, failing to obtain a conviction each time. Susan Finch, Family Upset Kyles Is Free, The Times-Picayune (New Orleans, La.), Feb. 19, 1998, at A13.

117 Muneer Deeb, for example, was acquitted in a January 1993 retrial after he spent seven years in prison for the 1982 stabbing deaths of three teenagers. Both the original prosecutor and the prosecutor at the retrial told the press they thought Deeb was guilty. See Barbara Kessler, Fighting the System, Dal.Las Morning News, Nov. 4, 1993, at 1A.

118 In January 1988, for example, William Jent and Earnest Miller pleaded guilty to second-degree murder in the 1979 slaying of Linda Bradshaw, despite the fact that they had always insisted on their innocence, and they were promptly set free because of the eight years they had spent on death row and time off for good behavior. See Athelia Knight, Pair Freed After Years on Death Row, WASH. Post, Jan. 16, 1988, at A3.

119 See Paula McMabon \& Andreas Tzortzis, Clearing of Convict Cracks DNA Door, SuNSentinel (Ft. Lauderdale, Fla.), Dec. 16, 2000, at 1A. Frank Smith, who spent fourteen years on death row for a 1986 murder, was exonerated by DNA testing in December 2000, eleven months after he had died on death row. $I d$.

120 In September 1994, for example, an Illinois judge ordered Joseph Burrows unshackled and released on his own recognizance to await retrial. Burrows had spent five years on death row. Dirk Johnson, Back to Family from Life on Death Roww, N.Y. Times, Sept. 24, 1994, at 22; see also Death Penalty Info. Ctr., supra note 111 (describing the releases of William Jent and Earnest Miller).

121 See E-mail from Michael L. Radelet, Professor of Sociology, University of Colorado, to Samuel R. Gross, Thomas G. and Mabel A. Long Professor of Law, University of Michigan Law School (Oct. 30, 2002, 13:10:04 CST) (on file with author). 
ences to the reactions of the victims' families, especially in recent years.

\section{A. Position on the Defendant's Innocence}

Do the victims' families agree that exonerated defendants are innocent? Judging from these stories, for the most part they do not. In only seven of our twenty-seven cases (slightly more than one-fourth) do the relatives indicate that they believe the defendants are in fact innocent, including one case in which the family initially said that the defendants were guilty but later changed their minds; in six cases they make ambiguous statements, or there were differences of opinion among family members; and in fourteen of the cases, over half, the relatives clearly continue to believe that the defendants are guilty. Sometimes the position is stated mildly: "I'm disappointed that the original conviction was overturned ...."122 Other times it is stated more forcefully: " $[\mathrm{S}]$ omebody, please, take care of this killer. I'm not asking anyone to harm [the defendant], I'm just begging for justice." 123 However, the basic sentiment is the same: "I believe the man got away with murder." 124

Why do the victims' families refuse to accept the innocence of these exonerated defendants? When Randall Adams was released from prison in Texas in 1989, he explained that the victim's relatives "have believed for 12 years that I was the killer. It may take them another 12 years to think differently." ${ }^{25}$ From a distance, it is difficult to doubt Adams's innocence. He was convicted of shooting a police officer from a car. ${ }^{126}$ The main witness against him was the driver, David Harris, a young man with an established history of violence and deception, and the real killer. ${ }^{127}$ Adams, it seems, was drunk and asleep at the time. ${ }^{128}$ Twelve years later, Harris-by then on death row himself for another murder-wrote a letter exonerating Adams. ${ }^{129}$ To continue to believe that Adams is guilty, one must discount Harris's letter, ignore the other problems in the case (and they are legion), and stubbornly stick to the initial judgment. Still, after

122 Steve Mills \& Ken Armstrong, Another Death Row Inmate Cleared, CH. Triв., Jan. 19, 2000 , at 1 (internal quotation marks omitted).

123 Stefanie Asin, Freedom Comes at High Price, Hous. Chron., Jan. 16, 1993, at A1 (internal quotation marks omitted).

124 Todd Spangler, In New Trial, Pennsylvania Man Acquitted of Murdering Four, AP, May 4, 2002 (internal quotation marks omitted), WEsTLAw, AP WiresPlus File.

125 Richard Luna, Adams Asks Officer's Family for Understanding, UPI, Mar. 23, 1989 (internal quotation marks omitted), LEXIS, New Library, UPI File.

126 Donald P. Myers, The Next Life of Randall Dale Adams (pt. 2), NewsDay, May 8, 1989, at 1,1989 WESTLAW 33376932.

127 Id.

$128 I d$.

$129 I d$. 
focusing their pain, their hatred, and their hopes for justice on Adams for so long, this was not a position the victim's family could easily abandon.

The position of the victim's family in the case of Rolando Cruz and Alejandro Hernandez is even more difficult to explain, at least on logical grounds. DNA tests not only absolved the defendants of the abduction, rape and murder of ten-year-old Jeanine Nicarico, for which they had been sentenced to death, but also identified the real criminal-Brian Dugan, a serial rapist and murderer who by then was serving a life term for another murder. ${ }^{130}$ Nonetheless, when Hernandez was freed the victim's father said, "It's a sad day for justice. Another murderer of our daughter is on the streets." 131 To hold to this view, he had to ignore the perjury and other official misconduct that produced the initial convictions, ${ }^{132}$ and accept a novel and bizarre theory that was inconsistent with the prosecution's position at the trial: that the original defendants somehow participated in the murder with Dugan, a man they apparently had never met. ${ }^{133}$ And yet, if we try to imagine the process from his point of view, Mr. Nicarico's reaction is not hard to understand. $\mathrm{He}$ and his wife sat for months in courtrooms with Cruz and Hernandez, certain that these men had kidnapped, raped, and killed their daughter. They did everything they could to help the police and the prosecutors get convictions and death sentences; they lived through the anxiety and turmoil of the trials; they worried that maybe those vicious killers would somehow manage to wiggle free. They rejoiced in the verdicts and mourned the reversals on appeal. After living with these defendants through years of trials and appeals and retrials-hating them, seeing them in their nightmares as the monsters who raped and killed their baby girl-is it surprising that the Nicaricos could not execute an about face and see Cruz and Hernandez not as evil killers but as victims of injustice?

The statements of some victims' relatives who do not continue to insist that the exonerated defendants are guilty also illustrate how hard it is for them to let go of their image of the defendant as the murderer. Walter McMillian was sentenced to death in Alabama in 1988 for murdering Ronda Morrison, largely on the basis of perjured testimony procured by the investigating officers. ${ }^{134}$ Five years after he

\footnotetext{
130 Eric Herman, Conspiracy Theory, Am. LAw., Mar. 1998, at 74.

131 Jeffrey Bils \& Ted Gregory, A Nightmare Ends, One Continues in Nicarico Case, CH. Trus., Dec. 9, 1995, at 1 (internal quotation marks omitted).

132 See Herman, supra note 130 , at $78-79$.

133 See id. at 82.

134 Arlene Levinson, At Death's Door: Black Man Freed After Witnesses Recant, Sunday GAZeTte-Mail (Charleston, W. Va.), Nov. 15, 1998, at 14A.
} 
was released in 1993, a wire-service article described Morrison's parents' reactions:

The trial and death sentence left them uneasy.

"We were afraid. What if he's not guilty?" said [Ronda's father, Charles Morrison], a retired pulp worker.

Still, they felt the matter was settled when McMillian was convicted, so his release reopened their wound. "I'm not saying whether the man is guilty or innocent," Morrison said. "But you know a jury proved him guilty. A jury did not prove him innocent." 135

In June I993, Kirk Bloodsworth, who was sentenced to death for raping and murdering a nine-year-old girl, became the first death row inmate to be exonerated by DNA evidence. ${ }^{136}$ The dead girl's father accepted Bloodsworth's innocence and expressed hope that maybe the real killer would be caught. But he also said that "he did not hold a grudge against Bloodsworth." 137 Rationally, of course, this makes no sense: why would he even think of holding a grudge against the man who was wrongly convicted of killing his child? In practical emotional terms, however, the father's statement rings true. It is as hard to give up a villain as a hero. It must have cost him a lot to come to accept Bloodsworth's innocence.

The process seems to start with the murder itself and the desperate need of many relatives of the victims to know who did it. On June 4, 1982, Clifford Williams's wife, Rebecca, was raped and murdered. In an interview in 2000 , Williams summed up in one word what life was like when police were still looking for the killer: "Hell." He stated:

"We didn't know who did it, why they did it or anything like that. I couldn't go back to the apartment." . . . "We didn't know who it was or what was going on. Would they come back and try to hurt one of us, or something? We had to escort the kids back and forth to school. ..."

"I felt better" when [Earl] Washington was arrested, he said. ${ }^{138}$

But Williams, like others in his terrible predicament, wanted to be sure. He went to the investigators: "[A]nd I asked them point-blank: 'Do you all know for sure that this is the man that did it?' And they told me, 'Yes, Clifford, beyond the shadow of a doubt. . ..'"139 He was reassured: "I wanted to be one of the witnesses to the execution

\footnotetext{
135 Id.

136 DNA Test Frees Man After Nine Years, St. Louis Post-Dispatch, June 29, 1993, at 7A, at 1993 WESTLAW 10174985.

137 Id.

138 Frank Green, Healing Hearts: 18 Years After His Wife's Murder, Cliff Williams Finds Family He Lost, Rich. Times-Dispatch, June 13, 2000, at D1.

$139 I d$. (internal quotation marks omitted).
} 
...."140 When DNA testing proved Washington innocent, Williams told a reporter that he felt

betrayed by the [county] authorities, who assured him that Washington was the right man and now won't talk to him .... "What do they have to hide? Why won't they talk about it?" he asked in a recent interview. "I went for nearly 18 years believing Washington did it. Now I don't know what to think." 141

There are two interlocking themes here: preoccupation with finding the real killer and trust in the local authorities who investigated the case. These themes are not unique to Mr. Williams. On the contrary, they crop up repeatedly and seem to explain why in some cases, relatives of the victims do accept the innocence of exonerated defendants, while in most cases they do not.

\section{B. 1dentifying the Real Killer}

In Walter McMillian's case, the father of the victim-who remains uncertain about McMillian's guilt-knows what he needs to settle his doubts: "I'll go hug [McMillan's] neck if they can prove somebody else did it . . . . 1 would apologize." 142 Again, logically this is a non sequitur. It is hardly McMillian's fault that the police have not found the real killer-quite the opposite: he was the chief victim of the bungled investigation that led the authorities astray-and it is certainly not his responsibility to find the real killer. But Mr. Morrison's impulse is easy to understand. If he must give up the man he has known as his daughter's killer, he wants a replacement. Other relatives in similar tragic circumstances seem to feel the same way. Not surprisingly, in five of the seven exonerations in which the victims' families accepted the defendants' innocence, they knew (or believed they knew) the identities of the real killers.

In two of these cases, the victims' families always thought the murders had been committed by people other than the defendants. In Anthony Porter's case in Chicago, the man whom the mother of one of the victims had suspected all along confessed and was prosecuted. ${ }^{143}$ And in the case of William Jent and Earnest Miller in Dade

\footnotetext{
140 Id. (internal quotation marks omitted).

141 Brooke A. Masters, Missteps on Road to Injustice, WASH. Post, Dec. 1, 2000, at A1.

142 Levinson, supra note 134 (internal quotation marks omitted).

143 Anthony Porter was convicted of the August 1982 murders of Marilyn Green and her fiancé, Jerry Hillard. Prior to Porter's exoneration, Green's mother signed a statement saying she had never believed that Porter had killed her daughter because they were friends, and repeatedly "told anyone who would listen ... that on the night her daugher was murdered, she left home in the company of Alstory Simon [the real murderer]." Eric Zorn, Evidence Grows that Wrong Man Is on Death Row, CH.1. TR1в., Feb. 2, 1999, at Metro 1; see also Jim Stingl, Retracting Confession Can Be a Real Killer, Milwaukef J. Sentinel, Dec. 14, 2001, at 1B (describing the Porter case); Giles Whittell, Snatched from Death's Door, Times (London), Mar. 19, 1999 (same), LEXIS, News Library, Ttimes File.
} 
City, Florida-both of whom pleaded guilty to second-degree murder to secure an immediate release-the victim's family always believed that she had been killed by her boyfriend. ${ }^{144}$ As a result, they had mixed feelings about the outcome: as the victim's sister said, "I'm glad that the boys are free, but now that they have admitted guilt, that means they [law enforcement officials] will never do anything to [the real murderer]." 145

In a third case in which the victim's family accepted an exonerated defendant's innocence, that of Peter Limone in Boston, the FBI apparently had framed four innocent men in addition to the two actual killers in a mob hit. ${ }^{146}$ In the case of Verneal Jimerson and Dennis Williams in Chicago, the prosecution was forced by DNA tests and other evidence gathered on behalf of the defendants to reopen the investigation and pursue the real killers, who had been fingered as suspects eighteen years earlier but ignored. ${ }^{147}$ And in Frank Smith's case in Fort Lauderdale, a DNA test not only exonerated him, but also identified the real killer-a serial rapist and murderer. ${ }^{148}$

\section{Trust in Local Law Enforcement}

Five years after Walter McMillian was released, the mayor of the town where the murder occurred told a reporter, "It's horrible for the Morrisons, because how do you know he's not guilty? .. . There must have been a reason. I trust all of our law officials." 149 Obviously, victims' relatives are not always happy with the performance of law-enforcement officials in capital prosecutions that later end in exonerations-we have seen several conspicuous counter examplesbut their initial inclination is to trust the government officers who are in charge of the case. As a result, the views of those who conducted the investigation have a powerful effect on the views of the victims' families. In nineteen of these twenty-seven cases, the news stories indicate that local prosecutors continue to believe that the exonerated defendants are guilty; the victims' relatives disagree in only one case, that of William Jent and Earnest Miller, in which the family always said that someone else was the killer. ${ }^{150}$ In three cases the position of the

\footnotetext{
144 Knight, supra note 118.

145 Id. (first alteration in original) (internal quotation marks omitted).

146 J.M. Lawrence, Men Jailed Wrongly in Mob Slay Clear Final Hurdle, Boston Herald, Jan. 31, 2001, at 5 .

147 James Hill, Man Guilty in Kidnap, Slayings of Couple, CH. Trıı., Apr. 29, 1997, at Metro 1.

148 Sydney P. Freedberg, He Didn't Do It, St. Petersburg Times, Jan. 7, 2001, at 1A, LEXIS, News Library, Stpete File. Smith died of cancer in prison before he was exonerated. Id.

149 Arlene Levinson, Some Survive Death Penalty, Chattanooga Times, Nov. 9, 1998, at A1 (internal quotation marks omitted).

150 See Knight, supra note 118.
} 
original prosecutors and police investigators is mixed or unclear; in two of the three, the victims' families are also divided, or their position is uncertain; ${ }^{151}$ in the third, they believe the defendant is innocent. ${ }^{152}$ In five cases the stories unambiguously show that the local authorities agree that the defendant is innocent, and in every one of those cases the family of the victim says so as well. ${ }^{153}$ We have found only two cases in which the victims' families believe that the defendant is innocent in the absence of a clear statement to that effect from the original prosecutorial office, and in both the families knew (or believed they knew) the identity of the real killers. ${ }^{154}$

The prosecution's position, in turn, seems to be determined by two basic aspects of the case: (1) The real killer. In three of the five cases in which the prosecutors agree that the defendants are innocent, the real killers were also identified: Verneal Jimerson and Dennis Williams; Anthony Porter; and Frank Smith. ${ }^{155}$ (2) DNA evidence. In four of these five cases the exonerated defendant was cleared by

151 In the case of Earl Washington, a retired meinber of the 4th Circuit Court of Appeals who heard one of Washington's appeals said that he had always suspected something was wrong with the case: "I wish I could have found a way to stop it . . I am delighted to hear about the pardon." Masters, supra note 141 (alteration in original) (internal quotation marks omitted). On the other hand, many of the investigating officers remained convinced of Washington's guilt. For example, Terry Schrum, the sheriff's deputy who was present at Washington's confession, said after Washington's release, "I feel as strongly about the case as I did back then." Id. (internal quotation marks omitted). The victim's widower apparently accepted Washington's innocence after DNA tests freed him, id., even though less than a month before the results of the DNA tests he said, "I can't believe anyone is even considering letting this man out where he can hurt somebody else. That man is guilty as sin." Brooke A. Masters, 'Time for Action' in Slaying Case, WASH. Post, Sept. 7, 2000, at B2 (internal quotation marks omitted). After the release of the test results, however, the victim's daughter said: "They let [Washington] go way too soon. I'm not comfortable with it." Brooke A. Masters, Va. Inmate to Get Back 'Good Time,' WASH. Post, Oct. 4, 2000, at BI (alteration in original) (internal quotation marks omitted).

After the exoneration of Walter McMillian, the original prosecutor said that he "did his job properly," while his successor-who Iater joined the defense in moving to have the case dismissed-said, "I believe he was framed by his former girlfriend and [another witness], and the police were cluped." Levinson, supra note 149, at Al (internal quotation marks omitted). The victim's parents' position was ambiguous. See Levinson, supra note 134.

152 A Boston Globe article covering the release of Peter Limone, convicted in 1965 for the murder of Edward Deegan, reports that "members of the FBI, the [U.S.] attorney's office, and Suffolk County district attorney's office vigorously lobbied against clemency for Limone and [a co-defendant] throughout the I980s and 1990s," but that "the prosecutor who had convicted Limone recommended commutation and Deegan's relatives said they believed Limone was innocent." Shelley Murphy, Parole Panelists Cite Retaliation After Vote, Boston Globle, June 19, 200I, at B2.

153 See Sharon Cotliar, Man Cuilly in '78 Slaying that Saw Four Wrongly Jailed, C1-11. SuNTIMEs, Apr. 29, 1997, at 10; McMahon \& Tzortzis, supra note 1 19; Sampat, supra note I13; Sandra Skowrow, Man Serving Time for Rape, Murder Freed After DNA Test, Com. APPEAL (Memphis, Tenn.), June 29, 1993, at A2, LEXIS, News Library, Comapp File; Zorn, supra note 143 .

154 See Knight, supra note 118; Zorn, supra note 143.

155 See supra text accompanying notes 143, 147-48. 
DNA identification evidence: Kirk Bloodsworth and Ray Krone, in whose cases the real murderers remain unknown; ${ }^{156}$ Jimerson and Williams, ${ }^{157}$ and Frank Smith, where the actual criminals have been found.158 A DNA test that excludes the exonerated defendant as a suspect certainly makes it more likely that the local authorities will accept his innocence, but hardly inevitable. In Earl Washington's case, the position of local officials (as reflected in the available news stories) is ambiguous, despite DNA evidence that led the governor of Virginia to grant Washington a full pardon. ${ }^{159}$ Charles Fain was cleared by DNA evidence, but the prosecutors continue to insist that he is guilty, ${ }^{160}$ and the original prosecutors continue to insist that Rolando Cruz and Alejandro Hernandez are guilty, despite the fact that DNA tests have shown that the semen recovered from the victim came from another man, a convicted murderer and confessed rapist. ${ }^{161}$

The importance of the prosecutors' position is illustrated by the case of Verneal Jimerson and Dennis Williams. When Williams was first released, on June 15, 1996, the prosecution took no clear stance on the defendant's guilt, but did reopen the investigation. ${ }^{162}$ Initially, Assistant State's Attorney Andrea Zopp stated, "What is clear is that our case as to these . . . defendants has drastically changed .... Our hope is that we can get some definitive answers as to what happened in 1978." 163 At that point, despite exculpatory DNA tests and a confession from one of the actual killers, a sister of one the victims was outraged: "I believe the right men were in prison ... . I sat through five different trials and five different juries. I don't believe that all the testimony we heard . . . would have [wrongly] incriminated all the people [it] did incriminate." 164 Within months prosecutors decided that the original defendants were indeed innocent, and prosecuted the real criminals. When the first was convicted on April 28, 1997, the same sister reached out to Mr. Williams in open court and said, "I'm sorry this happened." 165

It is easy to see why victims' families so often take their cue from law enforcement officials, particularly prosecutors. Murder is a rare

\footnotetext{
156 See supra notes $113,136-37$ and accompanying text.

157 See supra note 147 and accompanying text.

158 See supra note 148 and accompanying text.

159 See Masters, supra note 141.

160 See Teri Anderson, Former Death Row Inmate Freed, Post Register (ldaho Falls, Idaho), Aug. 24, 2001, at Al ("[The county prosecutor] believes there is some evidence Fain was involved in the crime, but it could not be proved beyond a reasonable doubt.").

161 See Bils \& Gregory, supra note 131.

162 Andrew Fegelman \& Terry Wilson, Men Imprisoned for '78 Murders Set Free on Bond, CH1. TR1в., June 15, 1996, at 5 .

163 Id. (internal quotation marks omitted).

$164 I d$. (second and third alternations in original) (internal quotation marks omitted).

165 Cotliar, supra note 153 (internal quotation marks omitted).
} 
event. The surviving victims and their families almost never have any experience of their own to draw on. Instead, they rely on those professionals for whom these exceptional and tragic events are commonplace. Most of us, at some point in our lives, find ourselves in similar situations in less extreme contexts: when we are injured or ill and consult a doctor, when we are sued and hire a lawyer, when our floor caves in and we call a contractor. In those situations we depend on the experts not just for advice and help but also for basic information. Without them, we do not know what is happening or what to expect. Prosecutors and police officers have all the authority of this powerful position, with three added advantages: First, they are public servants, presumptively worthy of our trust. Second, they have a monopoly; we can get a second opinion from a different doctor or fire one lawyer and hire another, but we cannot switch police departments or district attorneys' offices. Third, victims deal with them in an adversarial setting. In trial and in preparation for trial, prosecutors and police are on the victims' side in a battle with the defendants and their attorneys; inevitably, many victims and their families learn to see the legal proceedings from the prosecutors' point of view.

But precisely because prosecutors and police officers are professionals and, therefore, comparatively detached, they can disappoint the victims' relatives. For them, a criminal case, even a capital murder, is just business, not a personal tragedy. When a murder prosecution comes apart at the seams, they may respond in ways that the relatives consider unprincipled. We saw this in Clifford Williams's reaction to the police investigators after the case against Earl Washington unraveled: "What do they have to hide? Why won't they talk about it?" 166 And it happened to the Nicaricos after the Cruz and Hernandez exonerations. In September 2000, the chief prosecutor on the case recommended that the board of supervisors approve a $\$ 3.5 \mathrm{mil}$ lion settlement of the former murder defendants' civil lawsuit against the county. The victim's relatives "were particularly troubled because [the prosecutor] has assured them privately he still believes the ... men were involved in the nuurder." 167 Her father, Tom Nicarico, said, "I don't understand how a prosecutor can recommend paying off people he believes were involved in the murder. . . 1t blows my mind."168

\section{ConClusion}

Judging from what they say to the press, the most common reaction to an execution by victims' relatives is relief that it finally happened. The victims' relatives also frequently express satisfaction after

166 Masters, supra note 141 (internal quotation marks omitted).

167 Dan Rozek, Nicarico Settlement OKd, CHI. Sun-Times, Sept. 27, 2000, at 8.

$168 I d$. (internal quotation marks omitted). 
an execution, sometimes as impersonal approval that justice has been done, other times as unabashed pleasure in revenge. (The incidence of these reactions is probably exaggerated in our collection of news stories because the relatives who feel that way are more likely to come to executions and speak to the press than those who are unhappy about the event, or indifferent.) The long and complex route from trial to execution seems to contribute to the desire for justice and vengeance. Some relatives are offended or hurt by the attention that is repeatedly focused on the defendant throughout this process and view the execution as an opportunity to redress the balance-to do something for the victim. The very act of killing the defendant may, in their view, achieve that goal, and news stories about executions do, almost inevitably, discuss the victims and their families. But the central and most conspicuous character in the drama, once again, is the killer who is put to death. Finally, many relatives hope that at the point of death the killer will accept responsibility and apologize for his crimes, and that they will be able to forgive him. In a small number of cases that seems to be exactly what happens. Unfortunately, this scenario not only focuses on the condemned killer but requires his cooperation as well. Not surprisingly, relatives who want a sincere apology are usually disappointed and sometimes hurt.

For better or for worse, an execution is a conclusion. 1t may not heal the wounds of the victims' relatives, but it is the end point of a long and painful process. The exoneration of the condemned defendant is anything but a conclusion. It reopens the most basic question about the murder: Who did it? It means that the search for the killer must start over or come to naught. 1t is hardly surprising to find that most surviving relatives who speak to the press are unhappy with this outcome. Not only does it destroy their hope for an end to their ordeal, but to accept it they must also give up a view of the case and of the defendant that has been a central part of their lives for years. Most of them continue to believe in the exonerated defendants' guilt; to them, exoneration is just a strong version of the setbacks and reversals that are common on review of death sentences. In the minority of cases in which the relatives do accept the exonerated defendants' innocence they either believe they know the identity of the true killers, or the prosecutors and police officers who handled the cases-the victims' relatives' supposed advocates and guides to our adversarial system of justice-say that the exoneration was based on not just another legal technicality but on a genuine factual error.

In closing, it is useful to put the experiences of these victims' relatives in context. There are, as of this writing, over 3,700 prisoners on 
American death rows, ${ }^{169}$ and 200 or more new death sentences are returned each year, ${ }^{170}$ but the execution rate averages only about 75 per year. ${ }^{171}$ From 1973 through 1995, 5,826 death sentences were imposed in the United States; 17291 of those defendants have been exonerated $^{173}$ (about $0.2 \%$ ) and as of the end of 1995, 313 had been executed (about 5.4\%). ${ }^{174}$ To be sure, the number of executions and exonerations will increase a bit over time, but the basic picture is clear: only a small minority of death-sentenced prisoners are either exonerated and released or put to death. Most have their sentences reduced; a few are released for other reasons; some die in prison from other causes; the rest are stuck in the labyrinthine process of capital review. In all of these cases, the relatives of the victims go through the trauma of a capital trial and the appeals that follow to no end. In many, that process goes on indefinitely.

169 Deborah Fins, NaACP Legal Def. and Educ. Fund, Death Row U.S.A., Summer 2002, at 3, available at http://www.deathpenaltyinfo.org/DEATHROWUSArecent.pdf.

170 See Tracy L. Snell, U.S. Dep't of Justice, Capital Punishment 2000, at 9 (2000) (stating that 214 prisoners were sentenced to death in 2000).

171 See Fins, supra note 169 , at 11.

172 James S. Liebman et al., A Broken System, Part II: Why There ls So Much Error in Capmal Cases, and What Can Be Done About 1t 71 (2002), available at http://www. law.columbia.edu/brokensysteıns2/report.pdf.

173 One-hundred and two death row inmates have been exonerated and released since 1973. See Death Penalty lnfo. Ctr., supra note 5. From that total we subtract five who were convicted before 1973, and six who were convicted after 1995.

174 See LiEBMAN ET Al., supra note 172, at 71. 